\title{
PENGUJI MANIPULASI LABA REAL PADA PENGUNGKAPAN CORPORATE SOCIAL RESPONSIBILITY (STUDI EMPIRIS PADA PERUSAHAAN MANUFAKTUR DI BURSA EFEK INDONESIA)
}

\author{
Yateno dan Gustin Padwa Sari \\ Yatno.apta@gmail.com, harmony_fe@yahoo.com \\ Universitas Muhammadiyah Metro
}

\begin{abstract}
This study aims to examine empirically the effect of real earnings manipulation to CSR disclosure. A proxy for real earnings manipulation using models Roychowdhury (2006). CSR disclosure is measured using Corporate Social Disclosure Index (CSDI) based item reporting standard Global Reporting Initiative (GRI) are disclosed in the company's annual report. The study sample consisted of 261 manufacturing companies in 2012-2014. The results showed real earnings manipulation significant positive effect on CSR disclosure.

Keywwords: Earnings Manipulation, Corporate Social Responsibility, Manufacturing Companies.
\end{abstract}

\section{Pendahuluan}

\subsection{Latar Belakang}

Corporate Social Responsibility merupakan suatu konsep bahwa perusahaan tidak hanya bertanggungjawab terhadap pemilik modal (Stockholder), namun juga memiliki tanggungjawab terhadap seluruh pemangku kepentingan. Diantaranya konsumen, karyawan, pemegang saham dan lingkungan. Pengungkapan CSR mencerminkan akuntabilitas perusahaan atas pelaksanaan tanggung jawab sosial dan lingkungan, namun tidak setiap perusahaan mampu melakukan kegiatan CSR sesuai dengan konsep dasar CSR. Menurut CSR Indonesia, pengungkapan CSR di Indonesia masih bersifat pengiklanan diri dengan tujuan membangun reputasi. Terzaghi (2012) menyebutkan adanya penghargaan-penghargaan yang berkaitan dengan CSR dapat meningkatkan pengungkapan CSR perusahaan.

Pengungkapan CSR dilakukan karena perusahaan menginginkan citra positif, oleh karena itu perusahaan berupaya selalu menyampaikan hal yang positif mengenai perusahaan (Djumainah, 2011). Hal ini memungkinkan laporan tidak menggambarkan keadaan yang sebenarnya. Chih (2008) menyatakan aktivitas CSR dapat digunakan manajer untuk menghadapi konflik kepentingan untuk memaksimalkan tujuan pemegang saham dan pemangku kepentingan yang memiliki kepentingan yang berbeda. Manajer yang melakukan praktik manajemen laba memiliki dua alasan dalam memuaskan kepentingan stakeholder. Pertama, manajer mengantisipasi atas tindakan manipulasi laba dapat merugikan posisi mereka di perusahaan. Cara terbaik untuk mengantisipasinya adalah dengan memberikan kepuasan terhadap kepentingan stakeholder. Kedua, yaitu strategi pertahanan diri, manajer cenderung berkonspirasi dengan stakeholder yang lain sebagai strategi pelindung dalam praktik manajemen laba Arifin et al. (2012).

Penelitian ini menguji dampak manipulasi laba real pada pengungkapan CSR karena kegiatan CSR digunakan sebagai tameng oleh manajer perusahaan untuk menggalang dukungan dari para pemangku kepentingan. Prior et al. (2008) menyatakan bahwa manajer yang memanipulasi laba (earnings management) menggunakan pengungkapan kegiatan tanggung jawab sosial perusahaan (CSR) sebagai salah satu strateginya untuk menjaga hubungan dengan para stakeholder. 
Sebagaimana yang telah diungkapkan oleh Cespa dan Cestone, (2007) manajer menggunakan suatu strategi pertahanan diri (entrenchment strategy) untuk mengatasi ketidakpuasan stakeholder dengan kebijakan perusahaan tentang penerapan CSR.

Praktik CSR berpotensi dapat dihubungkan dalam pemenuhan kepentingan manajer sendiri. Seorang manajer mungkin terlibat dalam aktivitas CSR untuk menutupi dampak dari pelanggaran perusahaan (Hemmingway dan Maclagen, 2004). Ketika manajer terlibat dalam praktik CSR berdasarkan insentif opportusitik, maka mereka cenderung menyesatkan pemangku kepentingan mengenai nilai perusahaan dan kinerja keuangan (Kim et al., 2012). Dengan fokus pada latar belakang opportunistik ini, maka kita akan menguji apakah manipulasi laba dapat mendorong pengungkapan pertanggungjawaban sosial.

Beberapa peneliti sebelumnya Chih et al. (2008), Prior et al. (2008), Gargauri et al. (2010), Handajani et al.(2010), Mohammad et al. (2011), dan Arifin et al. (2012) mengungkap bahwa manipulasi laba berpengaruh positif dengan pengungkapan CSR. Namun, hal ini menimbulkan pertanyaan karena pada penelitian lain Yip et al., 2011; Hong dan Andersen 2011; Scholtens dan Kang, 2013; Kim et al., 2012; Pyo dan Lee, 2013 menyatakan bahwa perusahaan yang melakukan kegiatan CSR cenderung tidak memanipulasi laba.

Pyo dan Lee (2013) memberikan bukti empiris bahwa perusahaan yang melakukan aktivitas CSR cenderung melaporkan laba lebih berkualitas. Penelitian Kim et al. (2012) menunjukkan bahwa etika dapat mendorong manajer untuk menghasilkan laporan keuangan dengan kualitas yang tinggi. Perusahaan yang mengungkapkan tanggung jawab sosial cenderung berperilaku mengurangi manipulasi laba.berdasarkan banyaknya perbedaan hasil penelitian terdahulu, penelitian ini menjadi menarik karena banyak aspek yang dapat diteliti lebih luas mengingat kondisi perusahaan, sifat pengungkapan CSR, dan regulasi di Indonesia.

\subsection{Rumusan Masalah}

Berdasarkan uraian latar belakang diatas, maka masalah utama dalam penelitian yakni Apakah manipulasi laba real mendorong manajer untuk melakukan pengungkapan CSR?

\section{Landasan teori dan pengembangan hipotesis}

\subsection{Teori Stakeholder}

Keberadaan suatu perusahaan sangat dipengaruhi oleh dukungan yang diberikan stakeholder kepada perusahaan tersebut, Perusahaan bukanlah entitas yang hanya beroperasi untuk kepentingannya sendiri namun harus memberikan manfaat bagi stakeholdernya (pemegang saham, kreditor, konsumen, supplier, pemerintah, masyarakat, analis dan pihak lain) (Chariri: 2008). Dengan alasan tersebut, perusahaan akan melakukan aktivitas untuk mencari dukungan, semakin powerful stakeholder makin besar usaha perusahaan. Pengungkapan pertanggungjawaban sosial dilakukan perusahaan sebagai upaya dialog antara perusahaan dengan stakeholdernya.

Gargauri (2010) menyatakan bahwa dukungan stakeholder dapat mempengaruhi kelangsungan hidup perusahaan. Perusahaan harus mencari dukungan dengan melakukan aktivitas yang menunjukkan perhatian pada kepentingan stakeholder, sehingga pengungkapan tanggung jawab sosial dianggap sebagai cara yang ampuh untuk mendapat dukungan dari para stakeholder. 


\subsection{Teori political Cost}

Perusahaan besar yang lebih cenderung menggunakan pilihan akuntansi yang mengurangi laba yang dilaporkan dan/atau membuat pengungkapan lain untuk mengurangi biaya politik. Sebagai contoh, perusahaan-perusahaan dapat memilih untuk menggunakan metode akuntansi dalam mengurangi laba yang dilaporkan atau melakukan "kampanye tanggung jawab sosial di media" untuk mengurangi kemungkinan bahwa mereka akan menjadi sasaran aksi-aksi politik yang merugikan. Hal ini dilakukan dalam rangka mencegah transfer kekayaan dari perusahaan juga untuk kepentingan manajemen dan pemegang saham, sehingga dibawah perspektif biaya politik, hubungan antara pengungkapan CSR (sukarela) dan manajemen laba akan bervariasi tergantung pada lingkungan politik perusahaan (Yip et al., 2011).

\subsection{Corporate Social Responsibility}

Pengertian CSR menurut Pasal 1 butir 3 UU No. 40 Tahun 2007 tentang Perseroan Terbatas yakni, komitmen perseroan untuk berperan serta dalam pembangunan ekonomi yang berkelanjutan guna meningkatkan kualitas kehidupan dan lingkungan yang bermanfaat, baik bagi perseroan sendiri, komunitas setempat, maupun masyarakat pada umumnya.

Kegiatan pertanggungjawaban sosial juga diatur dalam PP Republik Indonesia No. 47 Tahun 2012 pasal 6 ayat 1 menyatakan "pelaksanaan tanggung jawab sosial dan lingkungan dimuat dalam laporan tahunan dan dipertanggungjawabkan kepada RUPS” pengungkapan kinerja ekonomi, lingkungan dan sosial dalam laporan keuangan tahunan adalah untuk mencerminkan akuntabilitas, responsibilitas dan transparansi perusahaan kepada investor dan stakeholder. Pengungkapan ini bertujuan untuk menjalin hubungan yang baik dan efektif antara perusahaan dengan publik dan stakeholder lainnya.

CSR merupakan tanggung jawab moral suatu perusahaan terhadap para stakeholders terutama komunitas atau masyarakat di sekitar wilayah kerja dan operasinya. Sebuah perusahaan harus menjunjung tinggi moralitas. Parameter keberhasilan suatu perusahaan dalam sudut pandang CSR adalah mengedepankan prinsip moral dan etis, yakni menggapai suatu hasil terbaik, tanpa merugikan kelompok masyarakat lainnya Anggraini (2006).

\subsection{Manipulasi Laba}

Manipulasi laba adalah intervensi manajemen dalam menyusun laporan keuangan sehingga dapat menaikkan atau menurunkan laba akuntansi sesuai kepentingannya. Beberapa penelitian manipulasi laba terdahulu fokus pada teknik manipulasi laba berbasis akrual, sedangkan manipulasi laba dengan hanya mendasarkan pada pengaturan akrual saja mungkin menjadi tidak valid. Dalam hal ini, menjadi penting untuk memahami bagaimana perusahaan melakukan manajemen laba melalui manipulasi aktivitas selain laba berbasis akrual (Roychowdhury, 2006).

Manajemen laba melalui transaksi real didefinisikan sebagai tindakan manajemen yang menyimpang dari praktik bisnis yang sesungguhnya dan dilakukan dengan tujuan utama memenuhi ekspektasi laba (Roychowdhury, 2006; Cohen, 2008). Zang (2008) memberikan bukti empiris bahwa tindakan manipulasi laba real dilakukan sebelum manipulasi laba berbasis akrual.

Menurut (Roychowdhury, 2006) manipulasi laba real dapat dilakukan dengan tiga cara yaitu:

a. Manipulasi penjualan 
Manipulasi penjualan merupakan usaha untuk meningkatkan penjualan secara temporer dalam periode tertentu dengan menawarkan diskon harga produk secara berlebihan atau memberikan persyaratan kredit yang lebih lunak. Strategi ini dapat meningkatkan volume penjualan dan laba periode saat ini, dengan mengasumsikan marginnya positif. Namun, pemberian diskon harga dan syarat kredit yang lebih lunak akan menurunkan aliran kas periode saat ini.

b. Penurunan beban-beban diskresionari (dicretionary expenditures)

Perusahaan dapat menurunkan discretionary expenditures seperti beban penelitian dan pengembangan, iklan dan penjualan, adminstrasi dan umum terutama dalam periode pengeluaran tersebut tidak langsung menyebabkan pendapatan dan laba. Strategi ini dapat meningkatkan laba dan arus kas periode saat ini, namun dengan risiko menurunkan arus kas periode mendatang.

c. Produksi yang berlebihan (overproduction)

Untuk meningkatkan laba, manajer perusahaan dapat memproduksi lebih banyak dari pada yang diperlukan dengan asumsi bahwa tingkat produksi yang lebih tinggi akan menyebabkan biaya tetap per unit produk lebih rendah. Strategi ini dapat menurunkan biaya barang terjual (cost of goods sold) dan meningkatkan laba operasi.

2.5 Pengembangan Hipotesis

Manipulasi Real dan Pengungkapan CSR

Motivasi manajemen melakukan manajemen laba real karena adanya tekanan maupun dorongan manajemen untuk meningkatkan laba jangka pendek serta rendahnya fokus manajemen terhadap rencana jangka panjang perusahaan. Perilaku oportunis manajemen memfokuskan kepada aktivitas-aktivitas yang dapat mempengaruhi laba, yaitu dengan manajemen laba real melalui ketiga aktivitas yaitu manajemen penjualan, overproduction, dan pengurangan biaya diskresioner. Hal ini dapat mengakibatkan manipulasi laba tidak hanya dilakukan dengan menggunakan diskresionary accrual saja. Roychowdhury (2006) menemukan bukti bahwa perusahaan menggunakan tindakan manajemen laba real untuk mencapai tujuan pelaporan keuangan tertentu selain untuk menghindari melaporkan kerugian. Oleh karena itu, manajemen yang melakukan manipulasi laba real menggunakan pengungkapan CSR sebagai upaya untuk menggalang dukungan dari para Stakeholder.

Ha: Manipulasi laba real berpengaruh positif terhadap pengungkapan pertanggungjawaban sosial.

\section{Metode Penelitian}

\subsection{Populasi dan Sampel}

Populasi dalam penelitian ini adalah semua perusahaan manufaktur yang tercatat (go public) di Bursa Efek Indonesia (BEI) untuk tahun 2012-2014. Tahun 2012-2014 dipilih dalam pengambilan sampel karena di tahun 2012 terbit peraturan baru PP Republik Indonesia No. 47 tahun 2012 tentang pelaksanaan kegiatan CSR. Perusahaan manufaktur yang tercatat di BEI digunakan sebagai populasi karena perusahaan tersebut memiliki kontribusi yang besar dalam memunculkan masalahmasalah sosial seperti polusi, keamanan produk dan tenaga kerja.

Penentuan sampel yang digunakan berdasarkan teknik purposive sampling. Adapun pada tahun 2012-2014 terdapat 403 perusahaan pengamatan. Sampel yang diperoleh yakni sebanyak 261 perusahaan yang telah memenuhi kriteria yang telah ditetapkan. Proses seleksi objek penelitian adalah sebagai berikut: 
Tabel 3.1

Proses Seleksi objek Penelitian

\begin{tabular}{|l|c|}
\hline \multicolumn{1}{|c|}{ Kriteria pemilihan sampel } & Jumlah \\
\hline Jumlah perusahaan manufaktur yang terdaftar di BEI 2012-2014 & 403 \\
\hline Data annual report perusahaan dalam dollar & $(70)$ \\
\hline $\begin{array}{l}\text { Jumlah perusahaan manufaktur yang tidak melaporkan annual report / } \\
\text { data tidak tersedia di Bursa Efek Indonesia (BEI) tahun 2012-2014 }\end{array}$ & $(50)$ \\
\hline $\begin{array}{l}\text { Data tidak lengkap terkait dengan variabel yang digunakan dalam } \\
\text { penelitian }\end{array}$ & $(22)$ \\
\hline Total objek penelitian & 261 \\
\hline
\end{tabular}

\subsection{Definisi Operasional Variabel}

1. Manipulasi Laba Real

Pengukuran manipulasi laba real diproksi dengan abnormal cash flows from operating, abnormal production costs, dan abnormal discretionary expenses dengan menggunakan model Roychowdhury (2006). Penelitian ini mengukur nilai abnormal dari ketiga manipulasi laba real diukur dengan residual dari model dan diestimasi per perusahaan (Kim et al. 2012).

a. Aktivitas abnormal cash flow of operation

$\mathrm{CFO}_{t} / A_{t-1}=\alpha 0+\alpha 1\left(1 / A_{t-1}\right)+\beta 1\left(S_{t} / A_{t-1}\right)+\beta 2\left(\Delta S_{t} / A_{t-1}\right)+e_{t}$

Untuk masing-masing perusahaan abnormal cash flow of operation $\left(A B \_C F O\right)$ adalah residual dari model.

b. Aktivitas production cost

$\operatorname{PROD}_{t} / A_{t-1}=\alpha 0+\alpha 1\left(1 / A_{t-1}\right)+\beta 1\left(S_{t} / A_{t-1}\right)+\beta 2\left(\Delta S_{t} / A_{t-1}\right)+\beta 3\left(\Delta S_{t-1} / A_{t-1}\right)+e_{t}$ Abnormal production costs (AB_PROD) merupakan residual dari model.

c. Aktivitas abnormal discretionary expenses:

$\operatorname{DISEXP}_{\mathrm{t}} / A_{t-1}=\alpha 0+\alpha 1\left(1 / A_{t-1}\right)+\beta\left(S_{t-1} / A_{t-1}\right)+e_{t}$

Abnormal discretionary expenses $\left(A B \_D I S E X P\right)$ merupakan residual dari model.

Dalam hal ini:

$\mathrm{CFO}_{\mathrm{t}}=$ Arus kas operasi pada tahun $\mathrm{t}$

PRODt = Beban produksi pada tahun $\mathrm{t}$ (total dari HPP dan perubahan persediaan)

DISEXPt = Biaya diskresioner pada tahun $\mathrm{t}$ (total dari $\mathrm{R} \& \mathrm{D}$, advertising, SGA)

St $\quad=$ Penjualan pada tahun $\mathrm{t}$

At $\quad=$ Total asset pada akhir tahun $\mathrm{t}$

$\Delta$ St $-1 \quad=$ St $-1-$ St

Penelitian ini menggunakan nilai absolut dari manipulasi laba real. Untuk menghitung nilai manipulasi laba real (Real Earnings Management), mengggunakan (AB_CFO), (AB_PROD), dan (AB_DISEXP). Dengan mempertimbangkan arah dari masing-masing aktivitas manipulasi laba, Maka REAL dihitung $\left(A B \_C F O\right)-\left(A B \_P R O D\right)+\left(A B \_D I S E X P\right)($ Cohen et al., 2008; Kim et al., 2012).

2. Pengungkapan Pertanggungjawaban Sosial (CSR)

Pada penelitian ini, pengukuran pengungkapan CSR menggunakan indikator yang dikeluarkan oleh Global Reporting Initiatives (GRI) versi 3.0 yang berjumlah 78 item. Pengukuran pengungkapan sosial menggunakan standar GRI pada penelitian sebelumnya dilakukan oleh Titisari (2010), Rahmawati (2011) 
dan Sari (2012). Indeks pengungkapan tanggung jawab sosial perusahaan (Corporate Social Responsibility Index) adalah penjumlahan dari seluruh itemitem CSR berdasarkan GRI yang diungkapkan di dalam laporan tahunan perusahaan dibagi dengan total item keseluruhan. Rumus perhitungan pengungkapan CSR adalah sebagai berikut:

$$
\text { CSRDIj }=\frac{\Sigma \mathrm{Xii}}{78}
$$

Keterangan:

CSRDIj : Corporate Sosial Responsibility Disclosure Index perusahaan j;

Xij $\quad$ : Dummy variable; $1=$ jika item i diungkapkan; $0=$ jika item i tidak

3. Variabel Kontrol diungkapkan Dengan demikian, $0 \leq \mathrm{CSRDIj} \leq 1$.

Variabel kontrol yang digunakan dalam penelitian ini adalah ukuran perusahaan (size), dan tipe industri. Variabel ukuran perusahaan (size) digunakan karena dapat mempengaruhi luas pengungkapan informasi dalam laporan keuangan mereka. Roychowdhury (2006) menjelaskan bahwa ukuran perusahaan dapat menjelaskan varian dalam manipulasi laba secara signifikan. Beberapa penelitian lain memberikan bukti bahwa ukuran perusahaan memberikan dampak pada pengungkapan pertanggungjawaban sosial (Prior et.al, 2008; Yip, 2011; dan Kim et. al, 2012).

Tipe industri digunakan untuk memisahkan tipe industri dalam manufaktur, yakni tipe industri high profile dan low profile (Anggraini, 2006; Sari, 2012). Tipe industri high-profile yaitu industri yang memiliki visibilitas konsumen, risiko politis yang tinggi, atau menghadapi persaingan yang tinggi akan cenderung mengungkapkan informasi sosial yang lebih banyak dibandingkan industri yang low-profile. Perusahaan-perusahaan yang termasuk dalam industri yang high-profile lebih banyak diawasi oleh pemerintah dibandingkan perusahaan yang termasuk dalam industri yang low profile (Anggraini, 2006). Sehingga, penelitian ini ingin melihat lebih jauh apakah manipulasi laba dapat mendorong pengungkapan CSR pada perusahaan dengan tipe industri high profile dan low profile.

Penelitian ini menggunakan penggolongan tipe industri perusahaan manufaktur sesuai dengan penggolongan yang telah dilakukan dalam penelitian Anggaini (2006) dan Sari (2012). Penelitian ini menggunakan industri manufaktur sebagai populasi penelitian sehingga perusahaan manufaktur yang termasuk dalam kategori high profile adalah perusahaan yang bergerak di bidang bahan kimia, plastik, kertas, automotif, makanan dan minuman, rokok, semen, farmasi, kosmetika, dan keperluan rumah tangga. Perusahaan manufaktur yang termasuk dalam kategori low profile adalah perusahaan yang bergerak di bidang keramik, logam, pakan hewan, kayu, mesin dan alat berat, tekstil, alas kaki, kabel dan elektronik.

\subsection{Pengujian Hipotesis}

Pengujian hipotesis dilakukan dengan menggunakan analisis regresi berganda, dengan model penelitian sebagai berikut:

CSRit $=\alpha 0++\beta 1$ REALit + ß2SIZEit + BINDUSTRIit + eit

Keterangan:

CSR : Corporate social responsibility

BO : Konstanta

ß1, ß2,ß3, ß4 : Koefisien 


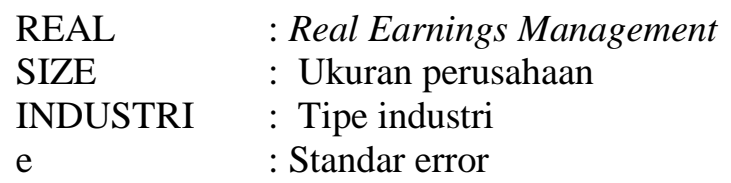

\section{Hasil Analisis}

4.1 Analisis Statistik Deskriptif

Data yang digunakan dalam penelitian ini adalah sebanyak 261 perusahaan manufaktur tahun 2012-2014 yang telah memenuhi kriteria yang ditetapkan. Analisis penelitiaan menggunakan aplikasi Eviews dengan hasil statististik deskritif sebagai berikut:

Tabel 4.1

Statistik Deskriptif

\begin{tabular}{|l|c|c|c|c|}
\hline & CSR & REAL & SIZE & INDUSTRY \\
\hline Mean & 0.192995 & 0.993075 & 14.22019 & 0.647510 \\
\hline Median & 0.179487 & 0.668071 & 14.07148 & 1.000000 \\
\hline Maximum & 0.435897 & 13.84323 & 19.27951 & 1.000000 \\
\hline Minimum & 0.038462 & 0.004027 & 9.267004 & 0.000000 \\
\hline Std. Dev. & 0.089748 & 1.185340 & 1.632871 & 0.478664 \\
\hline Skewness & 0.686634 & 5.341105 & 0.477095 & -0.617523 \\
\hline Kurtosis & 2.928345 & 54.42142 & 3.345845 & 1.381335 \\
\hline Jarque-Bera & 20.56464 & 29996.21 & 11.20221 & 45.08140 \\
\hline Probability & 0.000034 & 0.000000 & 0.003694 & 0.000000 \\
\hline Sum & 50.37181 & 259.1925 & 3711.469 & 169.0000 \\
\hline Sum Sq. Dev. & 2.094218 & 365.3080 & 693.2297 & 59.57088 \\
\hline Observations & 261 & 261 & 261 & 261 \\
\hline
\end{tabular}

Pengukuran pengungkapan CSR menggunakan indikator yang dikeluarkan oleh Global Reporting Initiatives (GRI) versi 3.0 yang berjumlah 78 item. Pengungkapan terkecil sebesar sebesar $3.8 \%$ dan pengungkapan terbesar $0.43 \%$. Selama tahun 2012-2014 pengungkapan CSR perusahaan manufaktur rata-rata sebesar 19.2\%. Manipulasi laba real diproksi dengan abnormal cash flows from operating, abnormal production costs, dan abnormal discretionary expenses, memiliki nilai terendah sebesar 0.004027 dan nilai tertinggi 13.84323 . Rata rata nilai manipulasi laba real sebesar 0.993075 hal ini menunjukkan perusahaan manufaktur pada tahun 2012-2014 rata-rata melakukan manipulasi laba real yang tinggi.

Size diukur dengan logaritma natural asset menunjukkan rata-rata sebesar 14.22019. nilai tertinggi 19.27951 dan nilai terendah sebesar 9.267004. asset menunjukkan kekayaan perusahaan. Semakin besar aset memungkinkan perusahaan melakukan pengungkapan CSR yang lebih besar. Tipe industri menggunakan variabel dummy. Nilai 1 untuk tipe industri high profile dan 0 untuk tipe industri low profile. Nilai rata-rata sebesar 0.647510 . 
TABEL 4.2

Hasil pengujian Hipotesis

Dependent Variable: CSR

Method: Least Squares

Sample(adjusted): 2261

Included observations: 260 after adjusting endpoints

Convergence achieved after 7 iterations

\begin{tabular}{crlll}
\hline \hline \multicolumn{1}{c}{ Variable } & Coefficient & Std. Error & t-Statistic & \multicolumn{1}{c}{ Prob. } \\
\hline \hline REAL & 0.009276 & 0.003913 & 2.370391 & $0.0185 *$ \\
SIZE & 0.022016 & 0.003071 & 7.168463 & $0.0000^{*}$ \\
INDUSTRY & 0.026576 & 0.013698 & 1.940057 & $0.0535 * *$ \\
C & -0.146738 & 0.044827 & -3.273396 & 0.0012 \\
AR(1) & 0.363737 & 0.059368 & 6.126842 & 0.0000 \\
\hline \hline R-squared & 0.301557 & Mean dependent var & 0.192604 \\
Adjusted R-squared & 0.290601 & S.D. dependent var & 0.089697 \\
S.E. of regression & 0.075548 & Akaike info criterion & -2.309052 \\
Sum squared resid & 1.455415 & Schwarz criterion & -2.240577 \\
Log likelihood & 305.1767 & F-statistic & 27.52442 \\
Durbin-Watson stat & 1.999365 & Prob(F-statistic) & 0.000000 \\
\hline \hline Inverted AR Roots & .36 & & \\
\hline \hline
\end{tabular}

*signifikan pada $\alpha(5 \%)$

*signifikan pada $\alpha(10 \%)$

Nilai Adjusted $R$-squared digunakan untuk mengetahui seberapa jauh variansi variabel-variabel bebas dapat mempengaruhi indeks pengungkapan CSR. Nilai Adjusted R-squared sebesar 0.29 menunjukkan besarnya peran atau kontribusi variabel manipulasi laba real, size dan tipe Industri mampu menjelaskan variabel indeks pengungkapan CSR sebesar 29\% sementara $71 \%$ dijelaskan oleh variabel lain. Nilai probabilitas sebesar $0.00<\alpha(5 \%)$ menjelaskan bahwa variabel manipulasi laba real, size dan tipe Industri berpengaruh terhadap indeks pengungkapan CSR.

\subsection{Pembahasan Hasil Penelitian}

Hasil pengujian menunjukkan menunjukkan $\beta 1$ sebesar 0.009276 dengan nilai signifikansi untuk sebesar $0.0185<\alpha(5 \%)$. Artinya penelitian ini memberikan bukti bahwa manipulasi laba real berpengaruh positif signifikan terhadap pengungkapan pertanggungjawaban sosial. Hasil penelitian ini senada dengan penelitian Kim et al. (2012) bahwa perusahaan yang menunjukkan pengungkapan CSR memanipulasi laba melalui aktivitas operasional perusahaan dan mengungkapkan pertanggungjawaban sosial untuk strategi pertahanan diri (entachment strategy) dalam mengantisipasi ketidakpuasan stakeholder.

Berdasarkan hasil analisis data nilai $\beta$ pada size sebesar 0.022016 dengan signifikansinya sebesar $0.000<\alpha(5 \%)$. Artinnya ukuran perusahaan (size) berpengaruh positif terhadap pengungkapan CSR. Hal ini menunjukkan ukuran perusahaan mempengaruhi luas pengungkapan informasi. Perusahaan besar 
mengungkapkan informasi lebih banyak karena memiliki risiko politis yang besar dan lebih banyak disoroti. Sehingga mengungkapkan CSR membantu perusahaan terhindar dari biaya akibat tuntutan masyarakat.

Nilai $\beta$ pada Industri sebesar 0.026576 pada tingkat signifikansi $0.0535<\alpha$ (10\%). Pengujian ini memberikan bukti bahwa tipe industri berpengaruh positif terhadap pengungkapan CSR pada tingkat keyakinan 90\%. Tipe industri high profile memiliki risiko politis yang tinggi, persaingan yang tinggi dan cenderung diawasi oleh pemerintah mengakibatkan perusahaan melakukan pengungkapan informasi sosial lebih banyak. Sehingga manipulasi laba dapat mendorong pengungkapan CSR lebih besar pada industri high profile.

\section{Simpulan dan Rekomendasi}

Penelitian ini menguji manipulasi laba real pada pengungkapan Corporate Sosial Responsibility (CSR). Pengungkapan CSR diukur dengan indikator 78 item pengungkapan CSR yang dikeluarkan oleh Global Reporting Intiatives (GRI) versi 3.0. Pengukuran manipulasi laba real diproksikan dengan abnormal cash flows from operating, abnormal production costs, dan abnormal discretionary expenses dengan menggunakan model Roychowdhury (2006). Hasil penelitian menunjukkan manipulasi laba real berpengaruh terhadap pengungkapan CSR.

Penelitian ini hanya terbatas pada perusahaan manufaktur. Untuk penelitian selanjutnya diharapkan dapat menguji perusahaan pada industri yang lain terutama pada perusahaan yang sensitif terhadap lingkungan dan sosial. Seperti perusahaan pada sektor pertambangan, dan perusahaan yang berkaitan dengan SDA yang dimaksud dalam UU No. 40 tahun 2007. Saran pada penelitian selanjutnya untuk memperpanjang sampel dan tahun pengamatan agar didapat gambaran dampak manipulasi laba real terhadap pengungkapan CSR menjadi lebih luas dan komprehensif.

\section{DAFTAR PUSTAKA}

Anggraini, Fr. Reni Retno. 2006. Pengungkapan Informasi Sosial dan Faktor-Faktor yang Mempengaruhi Pengungkapan Informasi Sosial dalam Laporan Keuangan Tahunan (Studi Empiris pada Perusahaan-Perusahaan yang terdaftar Bursa Efek Jakarta). Simposium Nasional Akuntansi IX. Padang.

Arifin, Bustanul. Yeni Januarsi dan Faoziah Ulfah. 2012. Perbedaan Kecenderungan Pengungkapan Corporate Social Responsibility : Pengujian terhadap Manipulasi Akrual dan Manipulasi Real. Makalah disampaikan pada Simposium Nasional Akuntansi XV, Banjarmasin.

Cespa, G. dan G. Cestone. 2007. Corporate Social Responsibility and Managerial Entrenchment. Journal of Economics and Management Strategy. 16 (3): 741-771.

Chariri, Anis. 2008. Kritik Sosial atas Pemakaian Teori dalam penelitian Pengungkapan Sosial dan Lingkungan. Jurnal Maksi. Vol. 8. No. 2 pp 151-169.

Chih, et.al. 2008. Corporate Social Responsibility, Investor Protection, and Earnings Management: Some International Evidence. Journal of Business Ethics. pp 79:179-198.

Cohen, Daniel, A., Dey, Aiyesha, and Thomas Z Lys. 2008. Real and Accrual-Based Earnings Management in the Pre- and Post-Sarbanes-Oxley Periods. The Accounting Review Vol. 83. No. 3, pp. 757-787.

Djumainah. Prima Yusi Sari dan Yoremia Lestari br. Ginting. 2011. Pengaruh 
Mekanisme Corporate Governance terhadap Manajemen Laba serta Implikasinya terhadap Pengungkapan CSR. Simposium Nasional Akuntansi XII, Purwekerto.

Gargauri, R. M. Claude Francour and Ridha Shabau. 2010. The Relationship between Corporate Social Performance and Earnings Management. Canadian Journal of Administrative Sciences. 27: 320-334

Handajani, Lilik, Sutrisno dan Grahita Chandrarin. 2010. The Effect of Earnings Management And Corporate Governance Mechanism to Corporate Social Responsibility Disclosure : Study at Public Companies in Indonesia Stock Exchange, Simposium Nasional Akuntansi XII Universitas Sriwijaya Palembang.

Hemingway, C., and P. Maclagan. 2004. Managers' personal values as drivers of corporate social responsibility. Journal of Business Ethics 50 (1): 33-44.

Hong, Yongtao dan Margaret Andersen. 2011. The Relationship Between Corporate Social Responsibility and Earnings Management: An Exploratory Study. Journal of Business Ethics. Vol. 104 Issue 4, p461-471, 11p (Abstrak).

Kim,Yongtae. Myung Seok Park and Benson Wiar. 2012. Is Earnings Quality Associated with Corporate Social Responsibility? The Accounting Review. Vol. 87 No. 3. 2012. Pp. 761-796.

Mohammad, Nor raihan et. al. 2011. The Effects Of Board Independence, Board Diversity and Corporate Social Responsibility On Earnings Management.

PP Republik Indonesia No. 47 Tahun 2012.

Prior, D., J. Surroca dan J.A. Tribo. 2008., Are socially responsible managers really ethical? Exploring the relationship between earnings management and corporate social responsibility. Corporate Governance : An International Review 16(3): 443-459

Pyo, Gyungmin dan Ho-Young Lee. 2013. The Association Between Corporate Social Responsibility Activities And Earnings Quality: Evidence From Donations And Voluntary Issuance Of CSR Reports. Journal of Applied Business Research. Vol. 29 Issue 3, p945-962, 18p (Abstrak)

Rahmawati, et.al. 2011. Analysis of the Effect of Corporate Social Responsibility on Financial Performance With Earnings Management as a Moderating Variable. Journal of Modern Accounting and Auditing, ISSN 1548-6583 Vol. 7, No. 10, 1034-1045

Roychowdhury, S. 2006. Earnings Management through Real Activities Manipulation. Journal of Accounting and Economics 42: 335-370

Sari, Rizkia Anggita. 2012. Pengaruh Karakteristik Perusahaan terhadap Corporate Social Responsibility Disclosure pada Perusahaan Manufaktur yang Terdaftar di Bursa Efek Indonesia. Jurnal Nominal. Vol 1. No 1.

Scholtens, Bert dan Feng-Ching Kang. 2013. Corporate Social Responsibility and Earnings Management: Evidence from Asian Economies. Corporate Social Responsibility \& Environmental Management. Vol. 20 Issue 2, p95-112, 18p (Abstrak).

Titisari, Kartika Hendra. 2010. Corporate Social Responsibility CSR dan Kinerja Perusahaan Makalah disampaikan pada Simposium Nasional Akuntansi XII, Purwekerto.

Terzaghi, Muhammad Titan. 2012. Pengaruh Earnings Management dan Mekanisme Corporate Governance terhadap Pengungkapan Tanggung Jawab Perusahaan Manufaktur yang terdaftar di Bursa Efek Indonesia. Jurnal Ekonomi dan Informasi Akuntansi. Vol 2. No. 1.

Undang-Undang Nomor 40 Tahun 2007 tentang Perseroan Terbatas 
Yip, Erica. Cris Van Steden and Steven Cahan. 2011. Corporate Social Responsibility Reporting and Earnings Management: The Role of Political Costs. Australian Accounting Business and Journal. Vol 5.

Zang, Y. Amy. 2012. Evidence on the Trade-Off between Real Activities Manipulation and Accrual-Based Earnings Management. The Accounting Review. Vol. 87 No. 2. Pp. 675-703. 